\title{
ANALISIS PENUNTUN PRAKTIKUM KIMIA SMA KELAS XI BERBASIS PROYEK DAN INQUIRY PADA MATERI HIDROKARBON
}

\section{ANALYSIS OF CHEMICAL PRACTICUM GUIDE AT CLASS XI SMA BASED ON PROJECT AND INQUIRY ON HYDROCARBON MATERIALS}

\author{
Eva Pratiwi Pane*, Hisar Marulitua Manurung \\ Program Studi Pendidikan Kimia, Universitas HKBP Nommensen Pematangsiantar \\ *Corresponding author: evapratiwi2607@gmail.com
}

\begin{abstract}
ABSTRAK
Penelitian ini bertujuan untuk mengembangkan dan mengetahui persepsi dosen dan guru serta tingkat kelayakan dan keterlaksanaan buku penuntun kimia inovatif terintegrasi berbasis proyek dan inquiry. Lokasi penelitian yaitu SMA Negeri 2 Pematangsiantar. Sampel penelitian adalah guru kimia dan 3 dosen kimia. Penuntun praktikum dinilai dengan presepsi oleh 20 guru kimia dan 3 dosen kimia dan telah layak memenuhi standart BSNP yang telah dimodifikasi. Buku penuntun inovatif dari persepsi dosen kimia dan guru kimia pada penuntun praktikum inovatif yang terintegrasi proyek dan inquiry pada materi Hidrokarbon Kelas XI SMA yang telah dikembangkan lebih mendukung pembelajaran dibandingkan buku penuntun yang ada dari berbagai penerbit, aspek yang dilihat dari aspek BSNP termodifikasi yaitu terdapat 7 aspek dalam uji kelayakan yaitu aspek kecakupan praktikum $(3,47)$, sistematika penyajian $(3,59)$, mengandung wawasan produktifitas $(3,89)$, merangsang keingintahuan $(3,76)$, mengembangkan kecakapan hidup $(3,81)$, desain $(3,83)$ dan bahasa $(3,59)$.
\end{abstract}

Kata Kunci: penuntun praktikum; proyek; inquiry.

\section{ABSTRACT}

This study aims to develop and determine the perceptions of lecturers and teachers as well as the level of feasibility and implementation of an integrated project-based and inquiry-based innovative chemistry guide book. The research location is SMA Negeri 2 Pematangsiantar. The research samples were chemistry teachers and 3 chemistry lecturers. The practicum guide was assessed by perception by 20 chemistry teachers and 3 chemistry lecturers and was worthy of meeting the modified BSNP standard. Innovative guidebooks from the perceptions of chemistry lecturers and chemistry teachers on innovative practicum guides that integrate projects and inquiries on Class XI High School Hydrocarbons material that have been developed are more supportive of learning than existing guidebooks from various publishers, aspects seen from the modified BSNP aspect, namely there are 7 aspects in the feasibility test, namely aspects of practicum coverage (3.47), systematic presentation (3.59), containing productivity insights (3.89), stimulating curiosity (3.76), developing life skills (3.81), design (3.83) and language (3.59).

Keywords: practical guide; project; inquiry.

\section{PENDAHULUAN}

Pendidikan proses belajar bertujuan untuk mengembangkan seluruh potensi yang ada pada diri siswa secara optimal, baik kognitif, afektif dan psikomotorik. Upaya peningkatan mutu pendidikan di Indonesia telah lama dilakukan, salah satunya adalah dengan mengadakan perombakan dan 
pembaharuan kurikulum yang berkesinambungan, mulai dari kurikulum 1968 sampai kurikulm 2013. Implementasai kurikulum 2013 di Indonesia sangat diharapkan dalam perbaikan mutu sumber daya alam manusia sebagai gambaran kualitas pendidikan memerlukan perhatian khusus dan berkelanjutan bagi semua pihak. Namun pada kenyataannya, mutu pendidikan di Indonesia masih rendah. Indikasi rendahnya mutu pendidikan di Indonesia sangat dirasakan pada pembelajaran eksakta, salah satunya adalah mata pelajaran kimia sebagai bagian dari mata pelajaran IPA (Suyanti, 2008). Pemerintah selalu berusaha untuk meningkatkan mutu pendidikan melalui berbagai kegiatan seperti pelatihan guru, perubahan dan penyempurnaan kurikulum, pemenuhan saran dan prasarana pendidikan, penerapan manajemen berbasis sekolah, sampai dengan tuntutan Undang-Undang Guru dan Dosen Tahun 2005. Akan tetapi Indikator ke arah peningkatan mutu pendidikan dirasakan lambat bila dibandingkan dengan tuntutan kemajuan IPTEK yang sangat cepat. Pendidikan harus dapat menyesuaikan diri dengan perubahan yang terjadi secara global sehingga peningkatan kualitas pendidikan harus selalu dilakukan secara terus menerus sesuai dengan situasi dan kondisi di Indonesia (Situmorang, 2013).

Strategi pembelajaran berorientasi aktivitas siswa dapat dipandang sebagai suatu pendekatan dalam pembelajaran yang menekankan kepada aktivitas siswa secara optimal untik memperoleh hasil belajar berupa panduan antara aspek kognitif, afektif, dan psikomotorik secara seimbang. Menurut Arends (2008) : ketrampilan kognitif maupun fisik adalah fondasi yang dibangun pembelajaran tingkat tingginya (termasul Learning to learn, belajar mengajar). Sebelum siswa dapat menenemukan berbagai konsep yang kuat, berpikir kritis, mengatasi masalah atau menulis secara kreatif, mereka mula-mula harus mendapatkan berbagai ketrampilan dan informasi dasar. Sebelum siswa berpikir kritis, mereka harus memiliki ketrampilan-ketrampilan dasar yang berhubungan dengan menarik logikal, deperti menarik kesimpulan dari data. Untuk mendorong kemampuan peserta didik menghasilkan karya konsteksual, baik individual maupun kelompok maka sangat disarankan untuk menggunakan pendekatan pembelajaran yang menghasilkan karya berbasis inkuiri (Pane, 2016).

Untuk mempermudah pemahaman siswa tentang suatu materi haris di dukung oleh penggunaan sumber belajar yang berkualitas. Sumber belajar (learning resources) merupakan suatu sumber baik data, orang dan wujud tertentu yang dapat digunkan oleh peserta didik dalam belajar baik secara terpisah maupun secara terkombinasi sehingga mempermudah peserta didik dalam mencapi tujuan belajar dan mencapi kompetensi tertentu. Secara garis besar, sumber belajar dapat berbentuk pesan, orang, bahan, alat atau perlengkapan, pendekatan atau metode teknik dan lingkungan .

Kegiatan pembelajaran harus dilakukakan secara interaktif, inspiratif, menyenangkan, menantang dan memotivasi peserta didik untuk berpartisipasi aktif, serta memberikan ruang yang cukup bagi prakarsa, kreativitas dan kemandirian sesuai dengan bakat, minat dan perkembangan fisik serta psikologi peserta. Istilah $\mathrm{R} \& \mathrm{D}$ kerja (penelitian dan pengembangan) menunjukkan bahwa terdapat setidaknya dua proses yang terjadi pada saat yang sama, praktik baik dieksplorasi dan dikembangkan. Pendekatan sistematis berarti bahwa wawasan penelitian difokuskan pada kegiatan dalam praktek itu adalah wawasan yang mewakili bagian sistematis dari pembelajaran. Inovasi Pembelajaran dalam buku penuntun praktikum dilakukan dengan beberapa pendekatan antara lain Penedekatan Scientific. Pendekatan Scientific dalam pembelajaran perlu diperkuat dengan menerapkan model pembelajaran berbasis Inquiry dan Proyek. Untuk mendorong kemampuan peserta didik menghasilkan karya konsteksual, baik individual maupun kelompok maka sangat disarankan untuk menggunakan pendekatan pembelajaran yang menghasilkan karya berbasis Inquiry dan Proyek (Munthe, 2011).

Pembelajaran dengan pendekatan Inquiry yaitu melatih peserta didik untuk mendapatkan jawaban-jawabannya sendiri berdasarkan temuannya atau menemukan lagi sesuatu yang ditemukan (dengan membuktikan kembali). Itu berarti, melalui pendekatan Inquiry yang memberikan kesempatan kepada peserta didik untuk mengembangkan ide dan gagasan dalam usaha untuk memecahkan masalah. Pembelajaran dengan pendekatan penemuan juga memberikan pemahaman kepada siswa dan lebih mudah diingat serta lama melekat. Dan metode pembelajaran berbasis Proyek adalah salah satu pendekatan yang diterapkan dalam proses kegiatan belajar mengajar.

Penuntun praktikum yang bermutu dan inovatif adalah salah satu fasilitas pendidikan penting yang perlu dikembangkan, khususnya dalam mata pelajaran kimia. Kimia sebagai bagian dari sains berkaitan dengan cara mencari tahu dan memahami alam secara sistematis. Seseorang yang 
mempelajari kimia tidak hanya membutuhkan keterampilan saja, tetapi juga diperlukan proses berfikir untuk memahami, menemukan, mengembangkan konsep, teori dan hukum serta pemecahan masalah dalam kehidupan sehari-hari (Sintawati, 2014).

Beberapa penuntun praktikum yang beredar dan pernah diterapkan oleh guru kimia di sekolah, di antaranya Kimia Berbasis Eksperimen Penerbit Platinum (2014), Panduan Praktikum Terpilih Penerbit Erlangga (2008), Buku Panduan Praktikum Manual Percobaan Penerbit Duta Nusantara (2013). Setelah dianalisis, buku-buku penuntun praktikum tersebut masih monoton, yakni pada penggunaan alat dan bahan di laboratorium, namun alternatif atau saran untuk penganti alat dan bahan dengan yang lain. Sementara tidak semua sekolah memiliki alat dan bahan praktikum seperti yang tertera dalam buku-buku tersebut. Akibatnya guru kesulitan untuk melakukan praktikum sesuai petunjuk buku penuntun, bahkan guru hanya mengajar teori tanpa melakukan praktikum sesuai tuntutan silabus pembelajaran.

Penuntun praktikum didefinisikan sebagai bahan ajar yang berisi pedoman dalam melakukan kegiatan praktikum di laboratorium dengan tujuan terciptanya kegiatan praktikum yang optimal dalam suatu proses pembelajaran. Laboratorium berperan penting dalam pembelajaran kimia untuk memahami konsep-konsep abstrak agar konsep tersebut dapat dengan mudah dipahami menjadi konsep yang konkret. Berdasarkan salinan Lampiran Peraturan Menteri Pendidikan Nasional Nomor 24 Tahun 2007 Tanggal 28 Juni 2007 bahwa ruang laboratorium adalah ruang untuk pembelajaran secara praktek yang memerlukan peralatan khusus. Selain itu, menurut Iqmal Tahir dan Eko Sugiarto dalam Manajemen Pelatihan Laboratorium menyatakan bahwa laboratorium kimia adalah tempat dilaksanakannya berbagai aktivitas yang melibatkan pemakaian bahan kimia tertentu. (BSNP). Penuntun praktikum perlu didesain semenarik mungkin, seiring dengan perkembangan Ilmu Pengetahuan dan Teknologi saat ini. Untuk itu dibutuhkan kreatifitas dalam menyusun penuntun praktikum yang inovatif agar menjadikan pembelajaran yang menarik bagi siswa.

Banyak penelitian mengenai media dan metode dalam pembelajaran Kimia telah dilakukan. Namun, hasil observasi di lapangan menunjukkan guru-guru kimia masih merasa kesulitan dalam mengajarkan ilmu kimia, terutama dalam pengajaran praktikum di laboratorium. Masih banyak dijumpai guru yang hanya mengajar teori tanpa melakukan praktikum yang seharusnya dilakukan berdasarkan silabus. Akibatnya siswa hanya mengingat dan menimbun berbagai informasi tanpa dituntut untuk memahami informasi dan mengaplikasikan informasi tersebut dalam kehidupan seharihari. Hal ini mengakibatkan ketika anak lulus sekolah, mereka hanya pintar secara teoritis tetapi sangat miskin aplikasi (Feyzioglu, 2009). Pernyataan ini diperkuat dengan pendapat Jahro (2009) bahwa ada terdapat 20 topik kimia yang ideal untuk dilakukan praktikum oleh siswa SMA/MA selama mereka belajar kimia di SMA, namun kenyataannya hanya 3,6 \% siswa yang hanya melakukan lebih dari 10 kali praktikum kimia di SMA/MA. Tidak maksimalnya pelaksanaan praktikum di sekolah disebabkan oleh beberapa faktor, di antaranya adalah praktikum hanya dengan diskusi atau demonstras, belum tersedianya penuntun praktikum kimia yang menjadi pedoman dalam melakukan praktikum kimia, guru juga belum memiliki panduan dalam menilai keterampilan proses sains dan sikap ilmiah, serta tidak tersedianya alat dan bahan praktikum yang mendukung kegiatan praktikum karena disebabkan oleh mahalnya alat dan bahan tersebut (Tuysuz, 2010).

\section{METODE PENELITIAN}

\subsection{Jenis Penelitian}

Penelitian ini termasuk penelitian pengembangan (research and development) yang dimodifikasi dari pengembangan pembelajaran model Borg \& Gall. Penelitian pengembangan (research and development) merupakan penelitian yang digunakan untuk menghasilkan produk tertentu dan menguji keefektifan produk tersebut (Sugiyono, 2010).

\subsection{Waktu dan Tempat Penelitian}

Penelitian dilakukan di Kota Pematangsiantar, Sumatera Utara. Penelitian dilaksanakan pada bulan Desember 2019 s/d Februari 2020. 


\subsection{Target/Subjek Penelitian}

Penilaian kelayakan terhadap buku praktikum inovatif dilakukan kepada 20 guru kimia dan 3 orang dosen kimia. Adapun yang menjadi validator dalam penelitian ini adalah 3 orang dosen kimia dan 20 orang guru kimia SMA yang dipilih secara random sampling baik negeri maupun swasta. Dosen yang dipilih sesuai dengan kriteria pendidikan minimal S2, sedang aktif mengajar dan menguasai materi Kimia Dasar yang relevan dengan materi kimia SMA. Guru kimia yang dipilih sesuai dengan kriteria telah mendapat pelatihan kurikulum 2013 dan memiliki kelayakan akademis S1 pendidikan kimia dan aktif dalam laboratorium.

\subsection{Prosedur}

Adapun prosedur pelaksanaan penelitian ini adalah penuntun praktikum untuk kelas XI SMA/MA yang telah dikembangkan dan diintegrasikan dengan nilai-nilai spiritual dinilai tingkat kelayakannya oleh 3 orang dosen ahli, yaitu dosen kimia dan 20 guru kimia kelas XI SMA yang ada di sekolah bisa dijangkau oleh peneliti kemudian disesuaikan dengan kurikulum 2013.

\subsection{Data, Instrumen, dan Teknik Pengumpulan Data}

Pada penelitian ini digunakan angket untuk menvalidasi penuntun praktikum dengan skala penelitian yang digunakan adalah 1 sampai 4 , artinya 1 sebagai skor terendah dan 4 sebagai skor tertinggi. Penentuan tentang dapat diketahui melalui rentang skor tertinggi dikurangi rata-rata yang digunakan (Arikunto, 2002) dapat dilihat pada Tabel 3.1 .

Tabel 1. Kriteria Validasi Penuntun Praktikum

\begin{tabular}{ccc}
\hline No & Rata- rata & Kriteria Variabel \\
\hline 1 & $3,26-4,00$ & Valid dan tidak perlu revisi \\
\hline 2 & $2,51-3,25$ & Cukup valid dan tidak perlu revisi \\
\hline 3 & $1,76-2,50$ & Kurang Valid , sebagian isi perlu direvisi \\
\hline 4 & $1,00-1,75$ & Tidak valid dan perlu revisi total \\
\hline
\end{tabular}

\subsection{Teknik Analisis Data}

Teknik yang digunakan pada penelitian ini adalah uji statistik menurut (Sudjana, 2005). Pada prinsipnya teknik analisa data digunakan untuk mengolah data dengan menggunakan metode statistik yang tepat untuk mecari kesimpulan.

Data yang telah didapat dari kesesuaian penuntun praktikum kelas XI semester I dianalisis secara tepat agar diperoleh kumpulan data yang tepat. Data yang diperoleh adalah data kuantitatif, berupa tanggapan dan saran perbaikan dari dosen dan guru terhadap penuntun praktikum yang diperoleh dari jawaban angket.

Data yang diperoleh kemudian dianalasis dengan langkah-langkah sebagai berikut:

1. Meganalisis kelayakan penuntun praktikum

2. Skala penilaian yang digunakan untuk menganalisis penuntun praktikum adalah 1 sampai 4 , dimana 1 sebagai skor terendah dan 4 sebagai skor tertinggi. Penentuan rentang dapat diketahui melalui rentang skor tertinggi dikurangi rentang skor terendah dibagi dengan skor tertinggi. Berdasarkan penentuan rentang tersebut diperoleh rentang 0,75 .

\section{HASIL DAN PEMBAHASAN}

Penuntun praktikum inovatif terintegrasi Proyek dan Inquiry yang disusun dan dikembangkan sesuai dengan kurikulum yang sedang diterapkan disekolah selanjutnya distandarisasikan melalui uji validitas dengan menggunakan angket nerdasarkan kurikulum 2013 dan BSNP (Badan Standar Nasional Pendidikan) dosen kimia dan guru kimia kelas XI di SMA Negeri 2 kota Pematangsiantar dan beberapa guru kimia yang mengajar di tingkat SMA/SMK.

Penuntun praktikum yang telah divalidasikan kemudian diperbaiki. Perbaiki terhadap penuntun praktikum dilakukan berdasarkan saran dan masukan yang telah diberikan oleh dosen dan 
guru. Adapun hasil dari analisis penuntun praktikum kimia yang telah divalidasikan oleh dosen dan guru adalah sebagai berikut:

\subsection{Aspek Cakupan Praktikum}

Hasil penelitian terhadap kelayakan Penuntun praktikum Inovatif terintegrasi Proyek dan Inquiry pada materi Hidrokarbon di SMA kelas XI berdasarkan Kecakupan Praktikum dapat dilihat pada grafik yang ada pada gambar 1 .

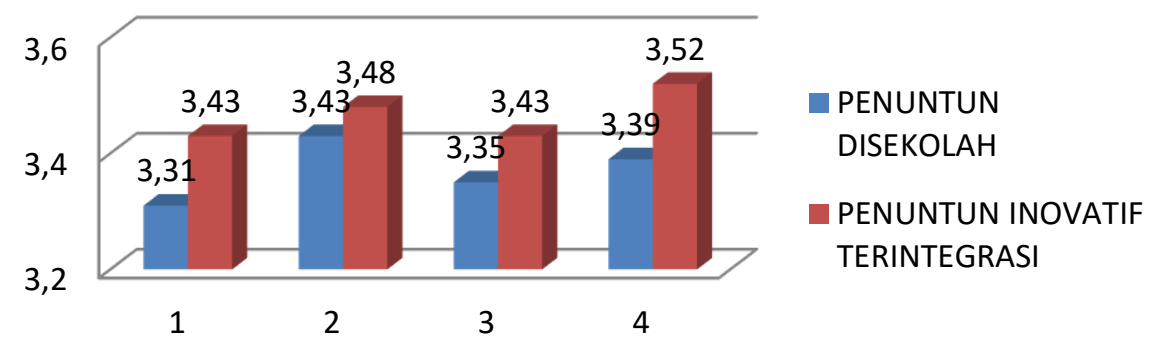

Gambar 1. Uji kelayakan penuntun praktikum inovatif terintegrasi proyek dan inquiry berdasarkan cakupan praktikum

Hasil uji kelayakan penuntun Praktikum materi hidrokarbon kelas XI SMA yang telah dikembangkan memiliki rata-rata 3,47 adalah valid, artinya sangat layak dan tidak perlu direvisi. Dan untuk penuntun praktikum disekolah memiliki rata-rata 3,36 adalah valid, artinya sangat layak dan tidak perlu direvisi.

Terdapat 4 komponen terkait aspek cakupan praktikum yaitu, 1) Keluasan Praktikum; 2) Kesesuaian Praktikum dengan KD dan KI; 3) Kesesuaian tujuan praktikum dengan indikator pembelajaran; 4) Kesesuaian Prosedur praktikum dengan model pembelajaran yang diterapkan. Nilai rata-rata cakupan praktikum tidak jauh beda secara signifikan dan terlihat sedikit perbedaan antara buku penuntun praktikum yang disekolah dan buku penuntun praktikum yang dikembangkan dengan terintegrasi berbasis Proyek dan Inquiry. Rata-rata nilai yang lebih tinggi terlihat dari buku penuntun praktikum yang dikembangkan dengan terintegrasi berbasis Proyek dan Inquiry dikarenakan peserta didik harus memiliki kreatifitas tersendiri sedangkan buku penuntun praktikum yang disekolah nilai rata-rata rendah karena sudah terbiasa dilakukan disekolah.

\subsection{Aspek Sistematika Penyajian}

Hasil penelitian terhadap kelayakan Penuntun praktikum Inovatif terintegrasi proyek dan inquiry pada materi hidrokarbon di SMA kelas XI berdasarkan Aspek Sistematika Penyajian dapat dilihat pada grafik yang ada pada gambar 2 .

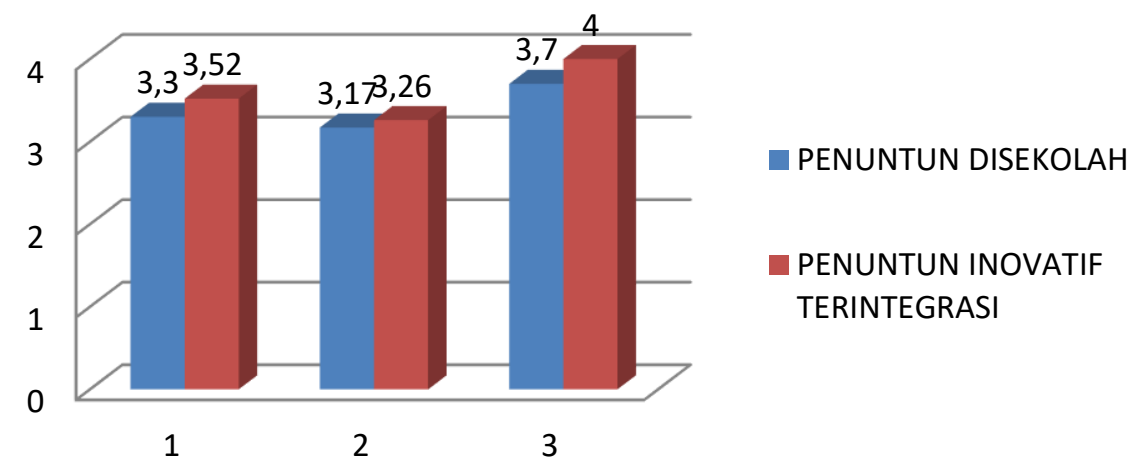

Gambar 2. Uji kelayakan penuntun praktikum inovatif terintegrasi proyek dan inquiry berdasarkan sistematika penyajian.

Hasil Uji Kelayakan Penuntun Praktikum Inovatif terintegrasi Proyek dan Inquiry pada materi Hidrokarbon pada kelas XI SMA pada aspek Sistematika Penyajian memiliki rata-rata 3,59 adalah 
valid, artinya sangat layak dan tidak perlu direvisi. Dan untuk penuntun praktikum disekolah memiliki rata-rata 3,40 adalah valid, artinya sangat layak dan tidak perlu direvisi.

Terdapat 3 komponen terkait aspek Sistematika Penyajian yaitu, 1) Kerunutan Susunan Penyajian; 2) Identitas tabel, gambar dan lampiran; 3) Prosedur Praktikum dijelaskan secara sistematis dan jelas. Nilai rata-rata sistematis Penyajian tidak jauh beda secara signifikan dan terlihat sedikit perbedaan antara buku penuntun praktikum yang disekolah dan buku penuntun praktikum yang dikembangkan dengan terintegrasi Proyek dan Inquiry. Rata-rata nilai yang lebih tinggi terlihat dari buku penuntun praktikum yang dikembangkan dengan terintegrasi Proyek dan Inquiry dikarenakan peserta didik harus memiliki kreatifitas tersendiri sesuai dengan pengalamannya sehari hari sedangkan buku penuntun praktikum yang disekolah nilai rata-rata rendah karena sudah terbiasa dilakukan disekolah dengan membaca prosedurnya.

\subsection{Aspek Mengandung Wawasan Produktifitas}

Hasil penelitian terhadap kelayakan Penuntun praktikum Inovatif terintegrasi Proyek dan Inquiry pada materi hidrokarbon di SMA kelas XI berdasarkan Aspek Mengandung Wawasan Produktifitas dapat dilihat pada grafik yang ada pada gambar 3.

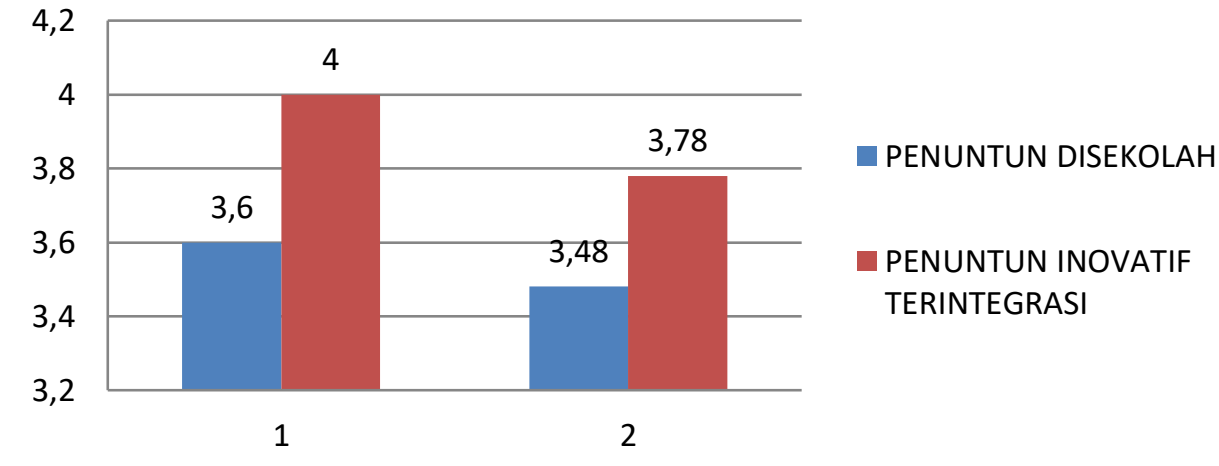

Gambar 3. Uji kelayakan penuntun praktikum inovatif terintegrasi proyek dan inquiry berdasarkan aspek mengandung wawasan produktifitas.

Hasil Uji Kelayakan Penuntun Praktikum Inovatif terintegrasi proyek dan Inquiry pada materi Hidrokarbon pada kelas XI SMA pada Aspek Mengandung Wawasan Produktifitas memiliki rata-rata 3,89 adalah valid, artinya sangat layak dan tidak perlu direvisi. Dan untuk penuntun praktikum disekolah memiliki rata-rata 3,52 adalah valid, artinya sangat layak dan tidak perlu direvisi.

Terdapat 2 komponen terkait aspek Mengandung Wawasan Produktifitas yaitu, 1) Menumbuhkan etos kerja; 2) Menumbuh semnagat berinovasi, kreatif dan kritis.

Nilai rata-rata komponen dari mulai menumbuhkan etos kerja sampai menumbuhkan semangat berinovasi, kreatif dan berpikir kritis pada penuntun praktikum yang disekolah dan buku penuntun praktikum yang dikembangkan dengan terintegrasi berbasis Proyek dan Inquiry memiliki perbedaan yang signifikan karena penuntun disekolah hanya melakukan sesuai dengan praktikum dengan mengukuti prosedur yang ada pada penuntun sedangkan penuntun praktikum yang dikembangkan dengan terintegrasi Proyek dan Inquiry dapat menumbuhkan semangat berinovasi, kreatif dan berpikir kritis, siswa pada penuntun ini merancang prosedurnya sendiri dan harus melakukan dan berpikir sendiri, jadi siswa dapat berinovasi, kreatif dan berpikir kritis dibandingkan dengan buku penuntun yang telah tersusun prosedurnya.

\subsection{Aspek Merangsang Keingintahuan}

Hasil penelitian terhadap kelayakan Penuntun praktikum Inovatif terintegrasi Proyek dan Inquiry pada materi hidrokarbon di SMA kelas XI berdasarkan Aspek Merangsang Keingintahuan dapat dilihat pada grafik yang ada pada gambar 4. 


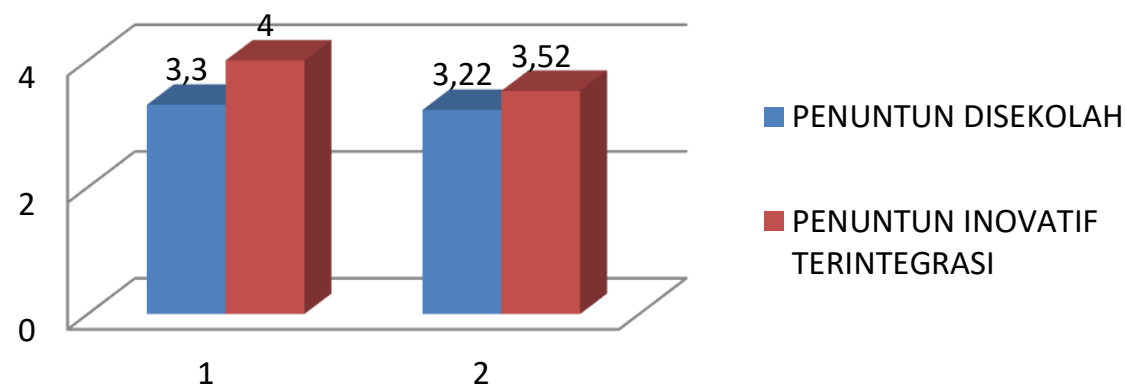

Gambar 4. Uji kelayakan penuntun praktikum inovatif terintegrasi proyek dan inquiry berdasarkan merangsang keingintahuan.

Hasil Uji Kelayakan Penuntun Praktikum Inovatif terintegrasi proyek dan Inquiry pada materi Hidrokarbon pada kelas XI SMA pada Aspek Merangsang Keingintahuan memiliki rata-rata 3,76 adalah valid, artinya sangat layak dan tidak perlu direvisi. Dan untuk penuntun praktikum disekolah memiliki rata-rata 3,26 adalah valid, artinya sangat layak dan tidak perlu direvisi.

Terdapat 2 komponen terkait aspek Merangsang Keingintahuan yaitu, 1) Menumbuhkan rasa ingin tahu dan 2) memberikan tantangan untuk lebih jauh. Nilai rata-rata komponen dari mulai menumbuhkan rasa ingin tahu sampai tantangan untuk lebih jauh pada penuntun praktikum Inovatif terintegrasi Proyek dan Inquiry memiliki perbedaan yang signifikan dengan buku penuntun praktikum yang ada disekolah, hal ini karena penuntun yang ada disekolah melakukan praktikum dengan mengikuti prosedurnya yang sudah ada dalam buku penuntun sedangkan pada penuntun praktikum Inovatif terintegrasi Proyek dan Inquiry dapat menumbuhkan rasa ingin tahu dan tantangan lebih jauh, siswa pada penuntun ini merancang proseduirnya sendiri dan harus sesuai dengan aturan dan arahan yang berlaku dalam buku penuntun praktikum.

\subsection{Aspek Mengembangkan Kecakapan Hidup (Life Skill)}

Hasil penelitian terhadap kelayakan Penuntun praktikum Inovatif terintegrasi Proyek dan Inquiry pada materi hidrokarbon di SMA kelas XI berdasarkan Aspek Mengembangkan Kecakapan Hidup (Life Skill) dapat dilihat pada grafik yang ada pada gambar 5.

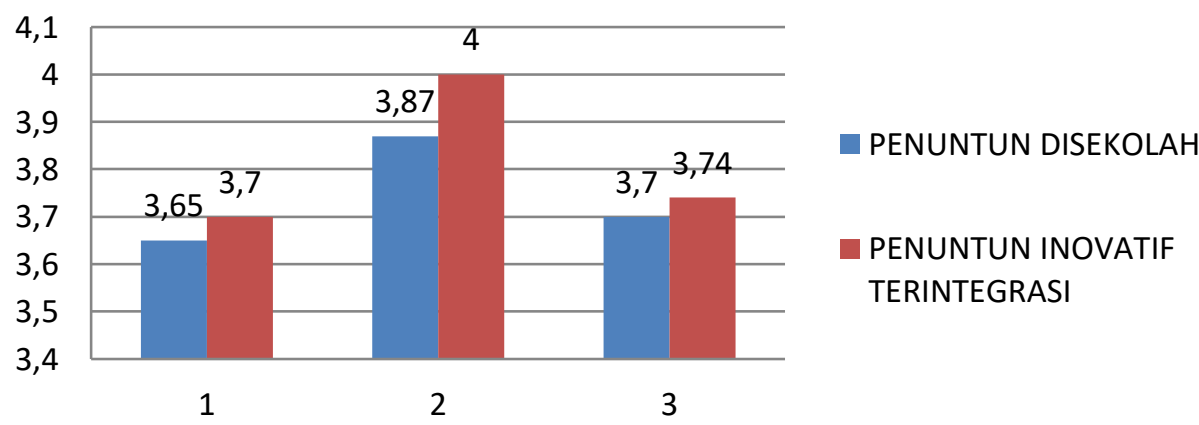

Gambar 5. Uji kelayakan penuntun praktikum inovatif terintegrasi proyek dan inquiry berdasarkan aspek mengembangkan kecakapan hidup (life skill).

Hasil Uji Kelayakan Penuntun Praktikum Inovatif terintegrasi Proyek dan Inquiry pada materi Hidrokarbon pada kelas XI SMA pada Aspek Mengembangkan Kecakapan Hidup (Life Skill) memiliki rata-rata 3,81 adalah valid, artinya sangat layak dan tidak perlu direvisi. Dan untuk penuntun praktikum disekolah memiliki rata-rata 3,73 adalah valid, artinya sangat layak dan tidak perlu direvisi.

Terdapat 3 komponen terkait aspek Mengandung Wawasan Produktifitas yaitu, 1) Mengembangkan Kecakapan Personal; 2) Mengembangkan kemauan akedemik dan 3) Mengembangkan kecakapan akademik.

Terlihat dari grafik pada komponen 1, 2 dan 3 yaitu tentang mengembangkan kecakapan personal dan mengembangkan personal yang lebih tinggi pada penuntun praktikum inovatif terintegrasi proyek dan inquiry dibandingkan dengan buku penuntun praktikum yang disekolah. Ini 
karena siswa mudah untuk menjelaskan sesuatu yang terjadi pada percobaan tersebut mengarahkan siswa untuk terampil dalam percobaan dan mampu melakukannya.

\subsection{Aspek Desain}

Hasil penelitian terhadap kelayakan Penuntun praktikum Inovatif terintegrasi Proyek dan inquiry pada materi hidrokarbon di SMA kelas XI berdasarkan Aspek Desain dapat dilihat pada grafik yang ada pada gambar 6 .

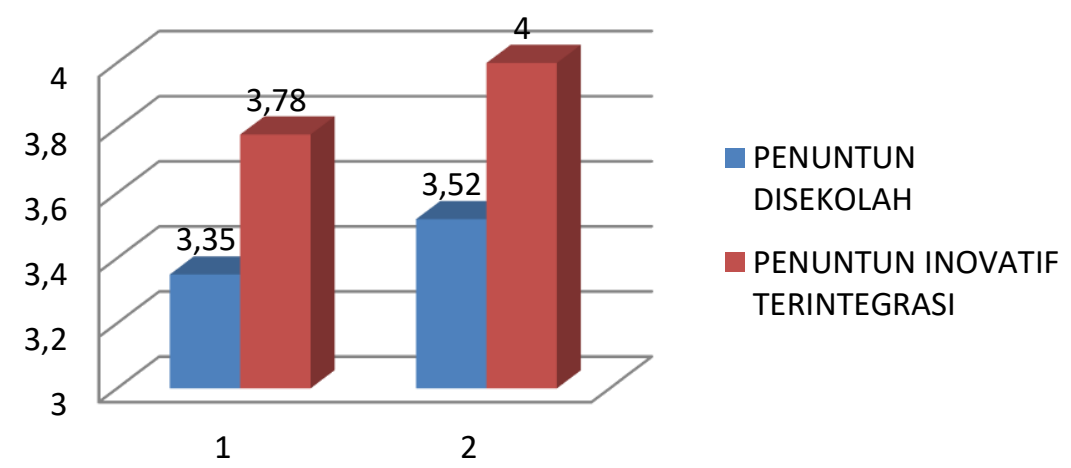

Gambar 3.6. Uji kelayakan penuntun praktikum inovatif terintegrasi proyek dan inquiry berdasarkan aspek desain

Hasil Uji Kelayakan Penuntun Praktikum Inovatif terintegrasi Proyek dan Inquiry pada materi Hidrokarbon pada kelas XI SMA pada Aspek Desain memiliki rata-rata 3,89 adalah valid, artinya sangat layak dan tidak perlu direvisi. Dan untuk penuntun praktikum disekolah memiliki rata-rata 3,43 adalah valid, artinya sangat layak dan tidak perlu direvisi.

Terdapat 2 komponen terkait aspek Desain yaitu, 1) Penyajian Gambar, tabel dan grafik; 2) Melibatkan siswa (interaktif).Terlihat dari grafik pada komponen 2 yaitu tentang melibatkan siswa (interaktif) yang lebih tinggi pada penuntun praktikum inovatif terintegrasi Proyek dan Inquiry dibandingkan dengan buku penuntun praktikum yang ada disekolah, hal ini dikarenakan siswa pada penuntun disekolah hanya mempraktekkan dengan apa yang sudah ada dalam buku penuntun tersebut sedangkan buku penuntun inovatif terintegrasi Proyek dan Inquiry diberi petunjuk sesuai dengan prosedur kerjanya dan guru hanya mengamati, memperhatikan siswa secara keseluruhan dan juga sebagai validator.

\subsection{Aspek Bahasa}

Hasil penelitian terhadap kelayakan Penuntun praktikum Inovatif terintegrasi Proyek dan Inquiry pada materi hidrokarbon di SMA kelas XI berdasarkan Aspek Bahasa dapat dilihat pada grafik yang ada pada gambar 7 .

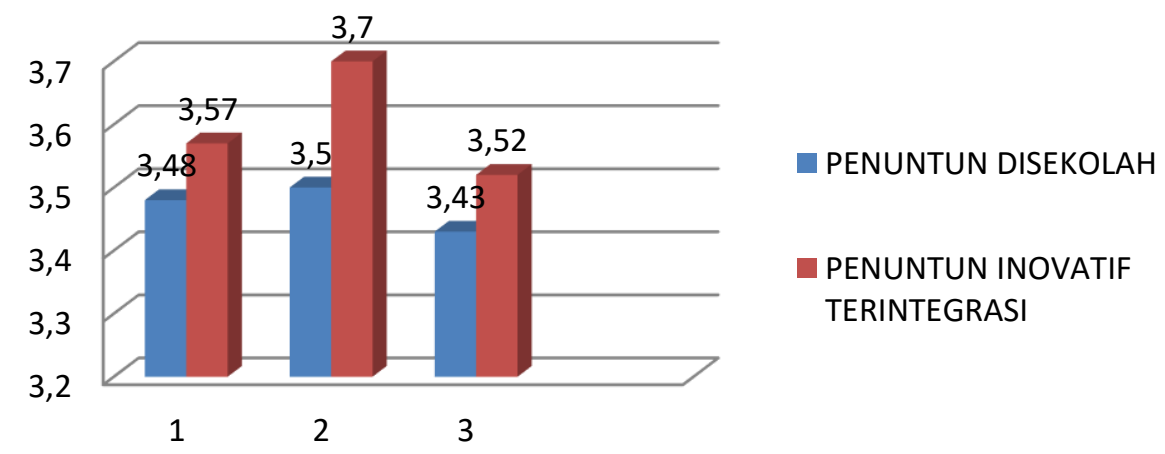

Gambar 7. Uji kelayakan penuntun praktikum inovatif terintegrasi proyek dan inquiry berdasarkan aspek bahasa 
Hasil uji kelayakan penuntun praktikum inovatif terintegrasi proyek dan inquiry pada materi hidrokarbon pada kelas xi sma pada aspek bahasa memiliki rata-rata 3,59 adalah valid, artinya sangat layak dan tidak perlu direvisi. Dan untuk penuntun praktikum disekolah memiliki rata-rata 3,47 adalah valid, artinya sangat layak dan tidak perlu direvisi.

Terdapat 3 komponen terkait aspek bahasa yaitu, 1) sesuai dengan perkembangan peserta didik; 2) komunikatif dan 3) konsisten penggunaan istilah dan simbol. Aspek bahasa dapat disimpulkan bahwa penuntun praktikum inovatif terintegrasi Proyek dan inquiry layak dipergunkan dan tidak perlu direvisi, sehingga kedua penuntun tersebut dapat dilakukan sesuai dengan perkembangan peserta didik dan bahasa yang digunakan dalam penuntun praktikum Inovatif terintegrasi Proyek dan Inquiry mudah dimengerti oleh siswa karena bahasa yang digunakan sering digunakan dalam kehidupan sehari-hari sedangkan buku penuntun praktikum yang ada disekolah bahasa yang ilmiah.

\section{SIMPULAN DAN SARAN}

\subsection{Simpulan}

Analisis dan penyajian menetapkan konsep dasar metode dan langkah-langkah berbasis proyek dan inquiry. Berdasarkan hasil data yang diperoleh, maka dapat diambil kesimpulan adanya buku penuntun praktikum inovatif yang terintegrasi berbasis proyek dan inquiry pada materi Hidrokarbon Kelas XI SMA yang dikembangkan telah dinilai oleh 20 guru kimia dan 3 dosen kimia, dan telah layak memenuhi standart BSNP yang telah dimodifikasi. Buku penuntun inovatif dari persepsi dosen kimia dan guru kimia pada penuntun praktikum inovatif yang terintegrasi proyek dan inquiry pada materi Hidrokarbon Kelas XI SMA yang telah dikembangkan lebih mendukung pembelajaran dibandingkan buku penuntun yang ada dari berbagai penerbit, aspek yang dilihat dari aspek BSNP termodifikasi yaitu terdapat 7 aspek dalam uji kelayakan yaitu aspek kecakupan praktikum diperoleh 3,47; sistematika penyajian doperoleh 3,59; mengandung wawasan produktifitas diperoleh 3,89; merangsang keingintahuan diperoleh 3,76; mengembangkan kecakapan hidup (life skill) diperoleh 3,81 ; desain diperoleh 3,89 dan bahasa diperoleh 3,59.

\subsection{Saran}

Berdasarkan hasil analisis data, maka disarankan beberapa hal sebagai berikut:

1. Dalam pembelajaran kimia khususnya praktikum pada materi Hidrokarbon, diharapkan guru mampu menggunakan praktikum inovatif yang terintegrasi proyek dan inquiry.

2. Dalam pembelajaran kimia dengan menggunakan praktikum, hendaknya guru tidak hanya sekedar mentransfer konsep-konsep kimia, melainkan memberi pemahaman lebih bagaimana konsep tersebut bisa terjadi,dipahami, dikuasai dan diaplikasikan.

3. Melihat penggunaan penuntun praktikum disekolah belum dikuasai oleh siswa karena tidak meratanya pemahaman siswa, hendaknya guru kimia benar-benar memperhatikan siswa dalam bekerja sama dan membuat siswa lebih kreatif dalam praktikum.

4. Untuk penelitian lanjutan dengan variabel yang relevan hendaknya dapat memperbaiki kekurangan yang ada pada penelitian ini dengan perencanaan yang lebih baik lagi untuk mendapatkan hasil yang diinginkan.

\section{DAFTAR PUSTAKA}

Abidin, Yunus. (2014). Desain Pembelajaran Dalam Konteks Kurikulum 2014. Pt Reflika Aditama.Bandung.

Arends. (2008). Learning To Teach: Belajar untuk mengajar. Terjemahan : Helly Prajitno Soetjipto dan sri Mulyantini soetjipto. Pustaka Pelajar : Yogjakarta.

Arikunto, S., (2002), Prosedur Penelitian, Penerbit Rineka Cipta, Jakarta.

Badan Standar Nasional Pendidikan. (2007). Model Silabus dan Rencana Pelaksanaan Pembelajaran. Mata Pelajaran: Ilmu Pengetahuan Alam. SMA/MTS. Digandakan oleh Kegiatan Penyelenggaraan Sosialisasi/Diseminasi/Seminar/Workshop/Publikasi Direktorat Jenderal Manajemen Pendidikan Dasar dan Menengah.

Chang, R. (2004). Kimia Dasar: Konsep-konsep Inti Jilid 2 Edisi Ketiga Erlangga. 
Emiliya, Rizki. (2015). Pengembangan Penuntun Praktikum Model Discovery Learning dan Project Based Learning pada Pembelajaran Asam dan Basa di SMA Kelas XI. Tesis. Unimed Press.

Feyzioglu, B., (2009), An Investigation of the Relationship between Science Process Skills with Efficient Laboratory Use and Science Achievementin Chemistry Education. Journal of Turkish Science Education 6(3):114-132.

Hosler, J., dan Boomer, K.B., (2011), Are Comic Books an Effective Way to Engange Nonmajors in Learning and Appreciating Science, CBE-Life Science Educational, 10: 309-317.

Indarti, dkk. 2013. Pengaruh Model Discovery Learning Terhadap Kemampuan Memecahkan Masalah Siswa Kelas X Sman 8 Malang

Jahro, I.S. (2009). Desain Praktikum Alternatif sederhana (PAS) Wujud Kreativitas Guru dalam Pelaksanaan Kegiatan Praktikum pada Pembelajaran Kimia. Jurnal Pendidikan Kimia1(2): 44-47.

Mahdjoubi, L., dan Rahman, M.A.A., (2012), Effect of Multimedia Characteristics on Notice CAD Learner's Practice Performance, Architectural Engineering and Design Management, 8: 214-225.

Masruroh, S. (2014). Implementasi Pendekatan Scientific pada Kurikulum 2013 untuk Meningkatkan MotivasiBelajar Siswa pada Bidang Kompetensi Teknologi Informasi dan Komunikasi.Prosiding Konvensi APTEKINDO ke 7 FPTK UPI Bandung.

Munthe, (2011), Analisis dan Standarisasi Buku Kimia Kelas X Semester 1 Berdasarkan Standar Isi KTSP. Tesis, Program Pasca Sarjana UNIMED, Medan

Nurrohman, Sabar. (2010). Pendekatan PJBL sebagai Internalisasi Scientific Method bagi Mahasiswa Calon Guru Fisika.Tesis. UNY. Yogyakarta.

Pane, Eva Pratiwi. (2016) Pengembangan Bahan Ajar Kimia Inovatif Berbasis Multimedia Untuk Meningkatkan Hasil Belajar Siswa Pada Pengajaran Laju Reaksi. Masters thesis, UNIMED.

Saefuddin, Asis. 2014. Pembelajaran Efektif. Pt Remaja Rosdakarya.Bandung.

Setyosari, Pinaji, (2012) Metode Penelitian Pendidikan dan Pengembangan Kencana, Jakarta.

Sintawati, Reni. (2014). Pengembangan Buku Petunjuk Praktikum Kimia SMA Berbasis Inkuiri Terbimbing Pada Materi Asam Basa. UIN Sunan Kalijaga Yogyakarta.

Situmorang, H. (2013). Efektivitas Metode Demonstrasi Dalam Meningkatkan Hasil Belajar Siswa Sekolah Menengah kejuruan Pada pengajaran Sistem Koloid. Jurnal Penelitian Bidang Pendidikan Volume 19(1): 28-36.

Sudjana, N., (2005), Penilaian Hasil Proses Belajar Mengajar, Bandung, PT Remaja Rosdakarya.

Suyanti, R., (2008), Pengembangan Metode Pembelajaran Kooperatif Tipe TAI dilengkapi Modul dan penilaian Portofolio untuk meningkatkan Prestasi Belajara Penentuan pH Reaksi Siswa SMA Kelas XI Semester I, Tesis, Prodi Kimia, Universitas Maret Surakarata.

Sugiono. (2010). Metode Penelitian Kuantitatif, Kualitatif, dan $R \& D$, Alfabeta, Bandung.

Tobing, F. (2012). Pengembangan Penuntun Praktikum Untuk Kelas X SMA Sesuai dengan Tuntutan KTSP, Tesis, Pascasarjana Universitas Negeri Medan.

Tuysuz, C. (2010). The Effect of the Virtual Laboratory on Students' Achievement and Attitude in Chemistry. IOJES 2(1): 37-53.

Yusraini. (2011). Penerapan Model Pembelajaran Berbasis Proyek Dengan Media Komputer Untuk Meningkatkan Hasil Belajar Dan Karakter Rasa Ingin Tahu Dan Menghargai Prestasi Pada Materi Asam Basa, Tesis, PPs, Unimed, Medan. 